\title{
TOWARDS MORE RESILIENT ECONOMIES IN ALPINE REGIONS
}

Riccardo Brozzi, Lucija Lapuh, Janez Nared, Thomas Streifeneder

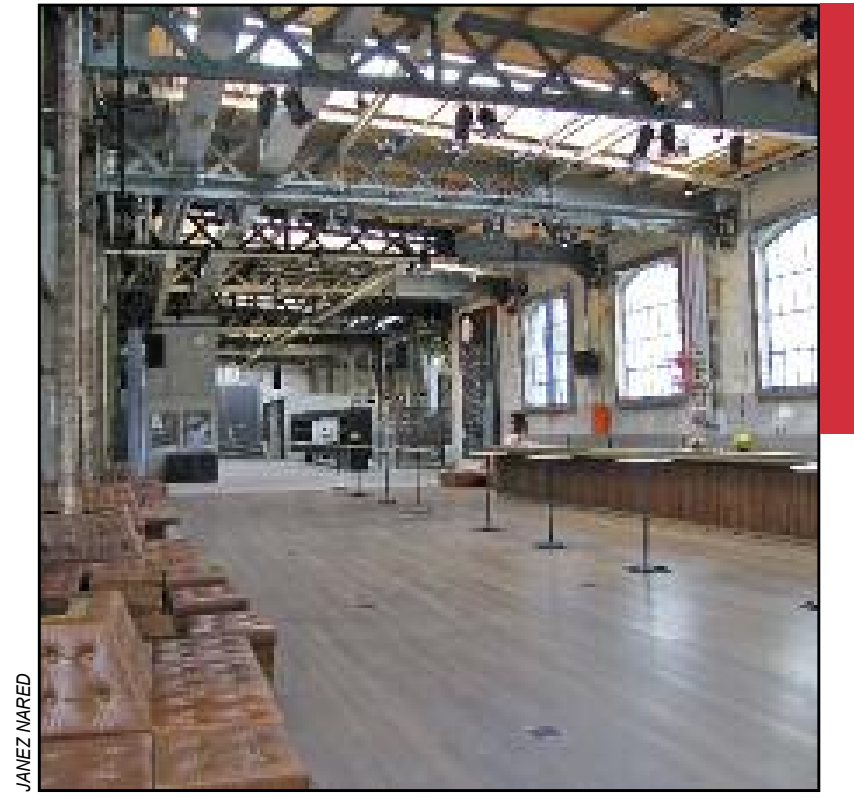

Regional economies are confronted with constant transformation, which is even more radical in times of economic crises. The picture shows the Schiffbau - the premises of former shipbuilding company in Zurich that were transformed into theatre. 


\title{
Towards more resilient economies in Alpine regions
}

DOI: http://dx.doi.org/10.3986/AGS.916

UDC: $911.3: 338.124 .4(234.3)$

COBISS: 1.01

\begin{abstract}
The economic crisis the world has faced since 2007 has had devastating effects on many regions to various degrees. How regions respond to economic shock depends on regional economic structure and performance, administrative capacity, resources, human capital, social capital, and other factors, and is perceived as resilience: the ability of a regional economy to withstand, absorb, or overcome an external economic stress. Because one of the future strategic goals for the Alpine Space Programme area is fostering its resilience, we studied the performance of Alpine regions in the pre- and post-crisis period in order to assess the effects of the economic crisis and to provide basic directions on how to make the Alps more resilient in the future. The results have revealed differences among three selected groups of regions as well as some country-specific characteristics of the regional response that can generally be seen in the weaker performance of some Italian and Slovenian regions.
\end{abstract}

KEY WORDS: geography, economic geography, regional planning, sustainable development, resilience, economic crisis, Alps

The article was submitted for publication on October $1^{\text {st }}, 2014$.

\section{ADDRESSES:}

\section{Riccardo Brozzi}

European Academy of Bozen/Bolzano

Institute for Regional Development and Location Management

Viale Druso, 1 / Drususallee 1, IT - 39100 Bolzano / Bozen, Italy

E-mail: riccardo.brozzi@eurac.edu

\section{Lucija Lapuh}

Anton Melik Geographical Institute

Research Center of the Slovenian Academy of Sciences and Arts

Gosposka ulica 13, SI - 1000 Ljubljana, Slovenia

E-mail: lucija.lapuh@zrc-sazu.si

\section{Janez Nared, Ph.D.}

Anton Melik Geographical Institute

Scientific Research Center of the Slovenian Academy of Sciences and Arts

Gosposka ulica 13, SI - 1000 Ljubljana, Slovenia

E-mail: janez.nared@zrc-sazu.si

\section{Thomas Streifeneder, Ph.D.}

European Academy of Bozen/Bolzano

Institute for Regional Development and Location Management

Viale Druso, 1 / Drususallee 1, IT - 39100 Bolzano / Bozen, Italy

E-mail: thomas.streifeneder@eurac.edu 


\section{Introduction}

The economic crisis that started in 2007 has presented many challenges to regional planners, who are trying to protect regions from negative effects and are seeking solutions for more resilient development in the future. Global economic changes have caused problems for both individuals and businesses, affecting entire economic sectors, regions, and their socioeconomic structures (cf. Bole 2011; Šprah, Novak and Fridl 2014; Aubert, Jónás-Berki and Gergely 2013). The Alpine Space Programme area is no exception. This was shown by a group of experts (Gloersen et al. 2012) that prepared key statements for strategy development for the Alpine Space Programme area. They identified six major external driving forces that influence Alpine regional development (climate change, uncertainties in energy supply, global market dynamics, the shift to a knowledge and information society, demographic change, and continuous growth in flows and persons) and defined fostering resilience of the Alps as one of the three objectives of the Alpine Space Programme's strategy for the period from 2014 to 2020: »the alpine space needs to become stronger in the face of increasing uncertainties. This implies identifying alpine communities' factors of vulnerability, and identifying how they could be less exposed to these risks. Resilience also presupposes an awareness of the core values to be preserved, and adaptations that would be accepted when needed " (Gloersen et al. 2012).

This article was prepared as part of the WIKIAlps project (Alpine Space Programme; WIKIAlps 2015). It analyses the economic resilience of Alpine regions, particularly the effects of the latest world economic crisis in Alpine regions, and provides some general recommendations on how to strengthen their economic resilience. We seek to determine which Alpine regions are more resilient and why it is necessary to determine components and indicators, and to define methodology to measure these.

\section{Approach and methods}

Most of the recent uses of the term resilience in regional or urban applications refer to the idea of the ability of local socio-economic systems to recover from a shock or disruption. Although the idea of resilience has been used for some time, it is only very recently that it has attracted attention from regional analysts, spatial economists, and economic geographers (Martin 2012). In economic geography, various concepts have developed to explain economies' resilience and their ability to recover quickly. Engineering resilience interprets it as the ability of a system to return to, or resume, its assumed stable equilibrium state or configuration following a shock. In ecological resilience, it is interpreted as the scale of shock or disturbance a system can absorb before it is destabilized and moves to another stable state or configuration (Martin 2012). Evolutionary economists argue that economies can never be in equilibrium (Simmie and Martin 2010) and that returning to pre-disaster normality is not always a suitable goal (Weichselgarner and Kelman 2014). The evolutionary approach focuses on historical processes (Boschma and Frenken 2011) and on the adaptive capability of a system (Martin 2012).

How do regional economies respond to recessionary and other shocks (Martin 2012)? The first aspect is that of resistance; that is, the vulnerability or sensitivity of a regional economy to disturbances and disruptions, such as recessions. The second aspect is that of the speed and extent of recovery from such a disruption. The third aspect concerns the extent to which the regional economy undergoes structural re-orientation and what implications such re-orientation has for the region's output, jobs, and incomes. The fourth dimension concerns the degree of renewal or resumption of the growth path that characterized the regional economy prior to the shock (Martin 2012).

Risk mitigation is a crucial factor for achieving the conditions for sustainable development of local systems (Graziano 2013). The role of regional institutions is crucial in resilience-building efforts through various risk-reduction strategies. Resilience literature also points to the needs of policy and practice. The strength and prosperity of any community, no matter how large or small, are enhanced by the resilience of its individuals and communities (Mock, Easterbrook and Banks 2013).

In the resilience literature there have been some attempts to measure regional resilience (including the Espon project: Economic crisis: resilience ... 2013; Hill, Wial and Wolman 2008; The Index ... 2011; Briguglio et al. 2008; Graziano 2013; Rizzi and Dallara 2011; Resilience Capacity Index 2013; Foster 2010). On the other hand, Weichselgarner and Kelman (2014) criticize this, stating that resilience and related indexes hide far more than they disclose. 
In this article, resilience is defined according to the Espon project (Economic Crisis: Resilience ... 2013) as the ability of a regional economy to withstand, absorb, or overcome an external economic stress. Resilience is suggested as being a positive framework comparable to vulnerability (Weichselgartner and Kelman 2014). We use the theoretical framework defined by applying it to a study on risk for Alpine regions. There have been many studies on the resilience of Alpine regions to natural hazards and socioecological change (e.g., Mock, Easterbrook and Banks 2013; von Glasenapp and Thornton 2011; Kuhlicke et al. 2011), but the resilience of Alpine regions' economies has not been sufficiently studied yet.

The concept of resilience seeks to understand the factors that affect the ability of regional economies to respond to changes and to recover from quite significant shocks. In measuring it, the gross domestic product (GDP) and the number of unemployed are the most visible regional variables that show economic and social wellbeing. According to the interim findings of the Espon project on economic crisis and resilience of regions (Economic crisis: resilience ... 2013) and other studies (Christopherson, Michie and Tyler 2010; Matarrita-Cascante and Trejos 2013), the following characteristics have the potential to positively influence regional economic resilience: prevailing endowments of physical capital and human capital; entrepreneurship and innovation; social capital, informal institutions, and network capital; governmental structures with greater levels of fiscal or legislative autonomy; the presence of a well-educated and skilled labor force and good qualifications of graduates; the flexibility of labor markets and higher levels of labor market participation; lower levels of unemployment; housing affordability; and the presence of a strong critical mass of urban-based activities. Stronger economies are more resilient than weaker ones, and economies that are more diverse tend to exhibit greater levels of resilience (Economic crisis: resilience ... 2013).

In analyzing the response of Alpine regions to the world economic crisis, we divided regions into three groups as defined by the Alpine Space Programme's transnational cooperation area (Alpine Space Programme ... 2014) and the Alpine Convention area (Ruffini et al. 2004). The first group is NUTS 3 regions entirely within the Alpine Convention area (thirty-eight regions; Swiss regions are not included), the second group is composed of regions partly in the Alpine Convention area (forty-four regions), and the third group is regions entirely outside the Alpine Convention area (seventy-nine regions). To compare the groups and analyze the crucial socioeconomic indicators in terms of performance and change before and after the crisis, we used a four-field chart reinterpreting the standard form of the portfolio matrix mainly employed in strategic management. The portfolio matrix was first developed by the Boston consulting group in order to position products or services that an enterprise delivers according to their market share and growth rate, depicted respectively in the $x$ - and $y$-axes of a four-field chart (Wöhe \& Döring 2010). In strategic management, this tool makes it possible to clearly position a set of products along the four categories defined in the matrix, according to the combination of high and low values of the indicators. In order to display the socioeconomic situation of regions before and after the crisis with the same effectiveness, we also employed a similar four-field chart. For the sake of our inquiry, such a tool was advantageous because it also showed whether movements occurred within different fields before and after the crisis.

In this way, we shaped the basic characteristics of the response of these groups of regions and interlinked them with current knowledge on resilience. We also used information to propose measures to make regions more resilient and less vulnerable to similar shocks in the future.

\section{Effects of the global economic crisis in 2007 on Alpine regions}

A number of scholars agree in considering the recent financial crisis one of the most severe economic crises in postwar economic history (Economic crisis in Europe ... 2009; Arestis et al. 2011; Helleiner 2011). Far from being limited to the instabilities of some of the world's largest private financial institutions, as it appeared to be at the early stages, the financial crisis gradually turned into a global economic crisis. In the European Union, the crisis interrupted fairly constant average GDP growth and employment growth, opening the doors of several countries to economic recession. Despite differences in the degree of impact, there is a widespread opinion that the effects of the crisis in the European Union can be observed starting from 2008 (Figures ... 2012). This chapter assumes that Alpine regions have not been immune to the downturn of key economic indicators, following the trends of other European countries. 
As Table 1 shows, all of the Alpine regions experienced negative GDP growth between 2008 and 2009. At the national (NUTS 1) and regional (NUTS 2) levels, the decline was relatively higher in Italy and Slovenia compared to the Alpine Space Programme NUTS 1 average. The slowdown of regional economic performances was particularly strong in Piedmont, Friuli-Venezia-Giulia, Lombardy, Eastern Slovenia, and Western Slovenia. Conversely, although negative, South Tyrol (Italy), Upper Bavaria (Germany), Provence-Alpes-Côte d'Azur (France), and Tyrol (Austria) experienced a relatively smaller decline, whereas in Burgenland the GDP growth rate did not vary compared to the previous year.

The development of socioeconomic indicators (GDP and employment growth rate) at the NUTS 3 level can be utilized to recognize intra-regional differences in the effects of the global economic crises (Lagravinese 2014) and therefore it is employed in the case of Alpine mountain economies. In addition, in order to achieve greater accuracy in evaluating whether the economic crises affected Alpine mountain economies to a greater or lesser extent compared to non-Alpine regions, three groups of NUTS 3 regions have been identified according to the Alpine Convention borders (Ruffini et al. 2004). The first group includes NUTS 3 regions entirely within the Alpine Convention border, the second those partly within Alpine Convention borders and the third NUTS 3 regions outside the Alpine Convention borders (Figure 1). GDP and employment growth development before and after the crisis are described using the concept

Table 1: GDP per capita at current prices (\% growth) in Alpine Convention NUTS 1/NUTS 2 regions (Statistical Office . . . 2014a; Federal Statistical Office 2014).

\begin{tabular}{|c|c|c|c|}
\hline NUTS 1/NUTS 2 regions & 2007-2008 (\%) & 2008-2009 (\%) & 2009-2010 (\%) \\
\hline $\begin{array}{l}\text { Austria } \\
\text { Carinthia } \\
\text { Styria } \\
\text { Salzburg } \\
\text { Tyrol } \\
\text { Vorarlberg } \\
\text { Upper Austria } \\
\text { Burgenland } \\
\text { Lower Austria }\end{array}$ & $\begin{array}{l}3.03 \\
2.49 \\
2.42 \\
1.57 \\
1.16 \\
3.46 \\
4.62 \\
1.82 \\
3.31\end{array}$ & $\begin{array}{r}-2.65 \\
-3.47 \\
-3.04 \\
-2.31 \\
-0.57 \\
-2.23 \\
-3.24 \\
0.00 \\
-3.20\end{array}$ & $\begin{array}{l}3.02 \\
3.24 \\
3.14 \\
3.68 \\
1.73 \\
2.56 \\
2.74 \\
3.13 \\
2.94\end{array}$ \\
\hline $\begin{array}{l}\text { Italy } \\
\text { Piedmont } \\
\text { Aosta Valley } \\
\text { Liguria } \\
\text { Lombardy } \\
\text { Trentino } \\
\text { South Tyrol } \\
\text { Veneto } \\
\text { Friuli-Venezia-Giulia } \\
\end{array}$ & $\begin{array}{r}\mathbf{0 . 3 8} \\
-0.69 \\
3.72 \\
2.17 \\
2.70 \\
0.32 \\
1.39 \\
-0.97 \\
-1.64 \\
\end{array}$ & $\begin{array}{l}-4.18 \\
-6.97 \\
-3.88 \\
-4.96 \\
-5.26 \\
-2.57 \\
-0.82 \\
-4.59 \\
-5.69 \\
\end{array}$ & $\begin{array}{r}1.98 \\
3.75 \\
3.73 \\
-0.37 \\
3.70 \\
1.65 \\
2.22 \\
1.37 \\
3.55 \\
\end{array}$ \\
\hline $\begin{array}{l}\text { France } \\
\text { Rhône-Alpes } \\
\text { Provence-Alpes-Côte d'Azur } \\
\end{array}$ & $\begin{array}{l}1.69 \\
2.35 \\
0.00 \\
\end{array}$ & $\begin{array}{l}-2.66 \\
-3.93 \\
-1.08 \\
\end{array}$ & $\begin{array}{l}2.05 \\
1.71 \\
2.55 \\
\end{array}$ \\
\hline $\begin{array}{l}\text { Germany } \\
\text { Upper Bavaria } \\
\text { Swabia }\end{array}$ & $\begin{array}{r}2.03 \\
-1.46 \\
2.76 \\
\end{array}$ & $\begin{array}{l}-3.65 \\
-1.72 \\
-2.68 \\
\end{array}$ & $\begin{array}{l}5.17 \\
4.51 \\
5.17\end{array}$ \\
\hline $\begin{array}{l}\text { Slovenia } \\
\text { Eastern Slovenia } \\
\text { Western Slovenia }\end{array}$ & $\begin{array}{l}7.60 \\
8.51 \\
6.28\end{array}$ & $\begin{array}{l}-5.98 \\
-6.54 \\
-5.45\end{array}$ & $\begin{array}{r}\mathbf{0 . 0 1} \\
0.01 \\
-0.48\end{array}$ \\
\hline $\begin{array}{l}\text { Switzerland } \\
\text { Lake Geneva Region } \\
\text { Espace Mittelland } \\
\text { Eastern Switzerland } \\
\text { Ticino } \\
\text { Central Switzerland }\end{array}$ & $\begin{array}{l}\text { N/A } \\
N / A \\
N / A \\
N / A \\
N / A \\
N / A\end{array}$ & $\begin{array}{l}-3.50 \\
-3.2 \\
-3.8 \\
-3.5 \\
-3.1 \\
-3.2\end{array}$ & $\begin{array}{l}2.30 \\
2.7 \\
3.0 \\
4.4 \\
2.1 \\
5.6\end{array}$ \\
\hline
\end{tabular}




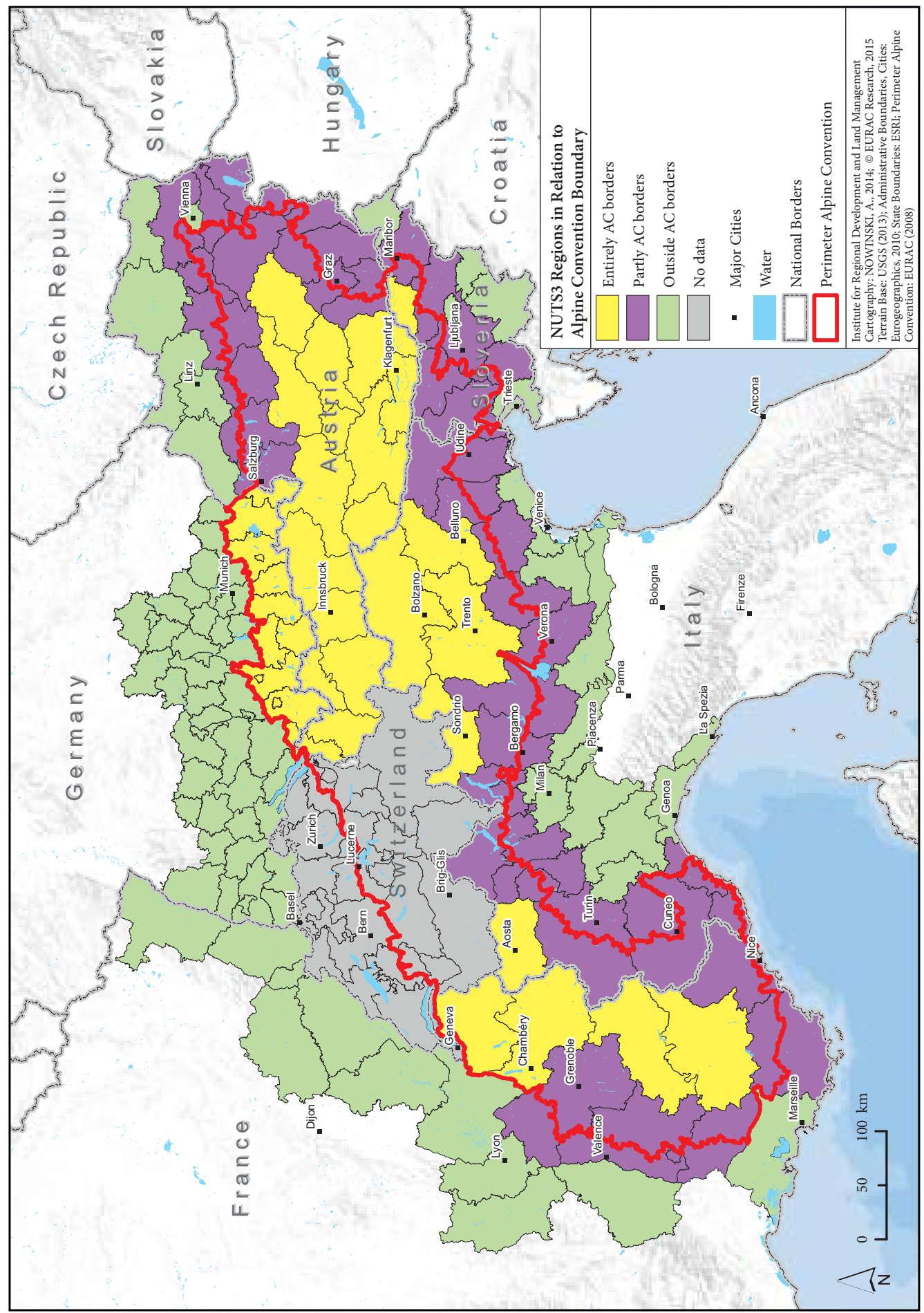

Figure 1: Groups of regions. 
of a portfolio matrix as graphical representation (Figure 2). The $x$-axis shows the yearly employment growth rate and the $y$-axis displays the yearly GDP growth rate for each NUTS 3 region for the three groups identfied. The combination of these two indicators synthetically returns in four distinct categories of the economic situation before the crisis (from 2004 to 2007) and economic development during the crisis period (from 2008 to 2011).

The three different charts show a diffuse contraction in employment and overall economic performance starting in 2008 in the three groups of regions identified. The majority of Alpine economies entirely within the Alpine Convention borders experienced a lower positive GDP and employment growth. However, in a limited number of cases, negative growth in both GDP and employment occurred in certain regions. Conversely, negative growth of both employment and GDP is visible in almost half of the regions partly included within the Alpine Convention borders. In this group of regions, a stronger downturn of economic indicators affected relatively more Italian and Slovenian NUTS 3 units. This trend is also followed by Italian and Slovenian regions outside the Alpine Convention borders, although to a lower extent. Table 2 shows how regions partly within the Alpine Convention borders on average experienced a more severe drop, particularly in yearly employment growth, although before the crisis the three groups of regions had similar economic performance.

A number of socio-economic factors may directly or indirectly explain why certain regions resist and recover heterogeneously to shocks; that is, why some regions are more resilient to crisis than others (Bristow 2014). As previously indicated, the findings support the argument for a stronger downturn of major economic indicators in those regions partly within the Alpine Convention borders, whereas no significant differences in the effect of the economic crisis seems to emerge between the other two groups of regions considered. An analysis of selected regional resilience indicators such as population change, GDP growth rates, and unemployment prior to the crisis (Bristow 2014) could be a valuable asset for outlining differences in regional resilience potential. However, the analysis shows that such markers for resilience (Table 2) are not significantly different among the three groups of regions selected. In particular, all of the regions exhibit similar average yearly GDP growth and unemployment rate prior to crisis. Against this trend, the outcome of the portfolio matrices indicates that employment in regions partly included shows lower growth and stronger contraction before and after the crisis period, respectively.

To conclude, this article identified which regions at the NUTS 2 and NUTS 3 levels have been more affected by the economic crisis considering the development of major structural economic indicators. It has to be acknowledged that at the NUTS 3 level a large majority of the indicators reflecting resilience characteristics are neither available nor adequate in terms of data completeness to allow regional comparison. However, the analysis of selected resilience indicators points to employment development as a potential negative marker for resilience in regions partly included in the Alpine Convention borders. This offers a preliminary result, which requires further research and more detailed data because explaining the potential causes of different degrees of resilience is a complex and multidimensional issue (Bristow 2014).

Table 2: Selected indicators for groups of regions examined (Statistical office ... 2014a, 2014b, 2014c, 2014d).

\begin{tabular}{lccc}
\hline Category & $\begin{array}{c}\text { Entirely in the Alpine } \\
\text { Convention area }\end{array}$ & $\begin{array}{c}\text { Partly in the Alpine } \\
\text { Convention area }\end{array}$ & $\begin{array}{c}\text { Outside the Alpine } \\
\text { Convention area }\end{array}$ \\
\hline Average GDP, 2007 (€/inhabitant) & $28,286.84$ & $26,922.73$ & $29,435.55$ \\
Yearly GDP growth rate (2000-2007) & $3.11 \%$ & $3.65 \%$ & $2.95 \%$ \\
Yearly GDP growth rate (2004-2007) & $2.86 \%$ & $3.13 \%$ & $2.81 \%$ \\
Yearly GDP growth rate (2008-2011) & $0.96 \%$ & $1.26 \%$ & $0.88 \%$ \\
Average unemployment rate 2007 & $4.20 \%$ & $4.21 \%$ & $4.70 \%$ \\
Yearly employment growth rate (2004-2007) & $1.32 \%$ & $0.05 \%$ & $1.23 \%$ \\
Yearly employment growth rate (2008-2011) & $0.30 \%$ & $-0.38 \%$ & $0.29 \%$ \\
Yearly population change (2003-2007) & $0.34 \%$ & $0.67 \%$ & $0.43 \%$ \\
\hline
\end{tabular}


Riccardo Brozzi, Lucija Lapuh, Janez Nared, Thomas Streifeneder, Towards more resilient economies in Alpine regions
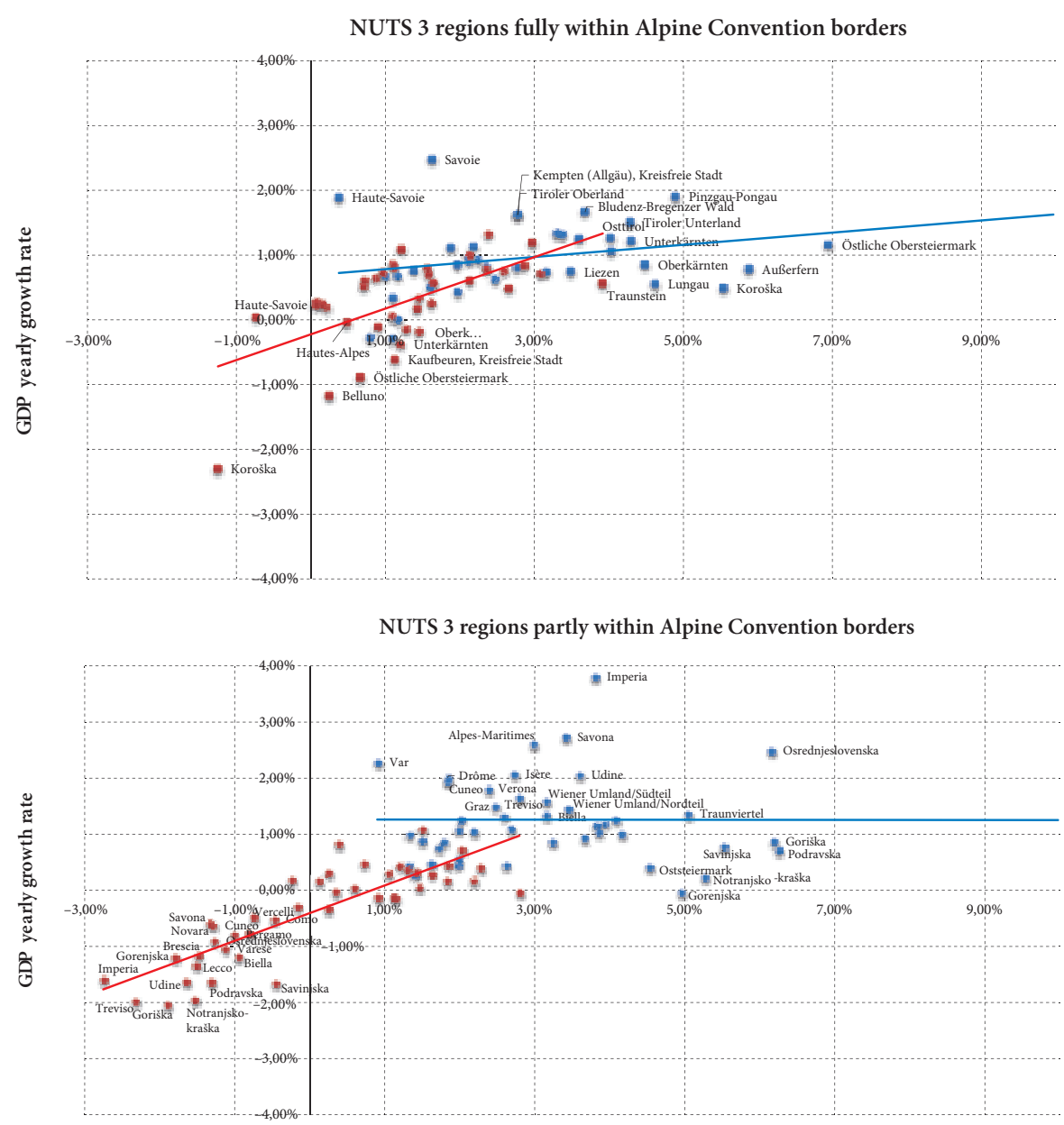

NUTS 3 regions outside Alpine Convention borders

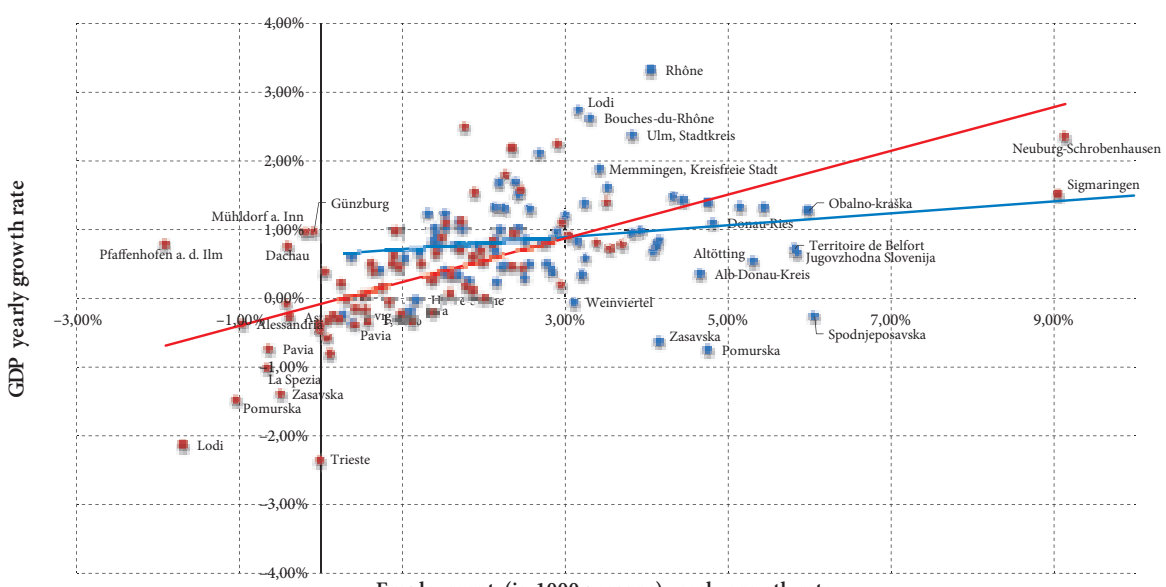

Employment (in 1000 persons) yearly growth rate

- Series1 - Series2 — Linear (Series1) — Linear (Series2) 


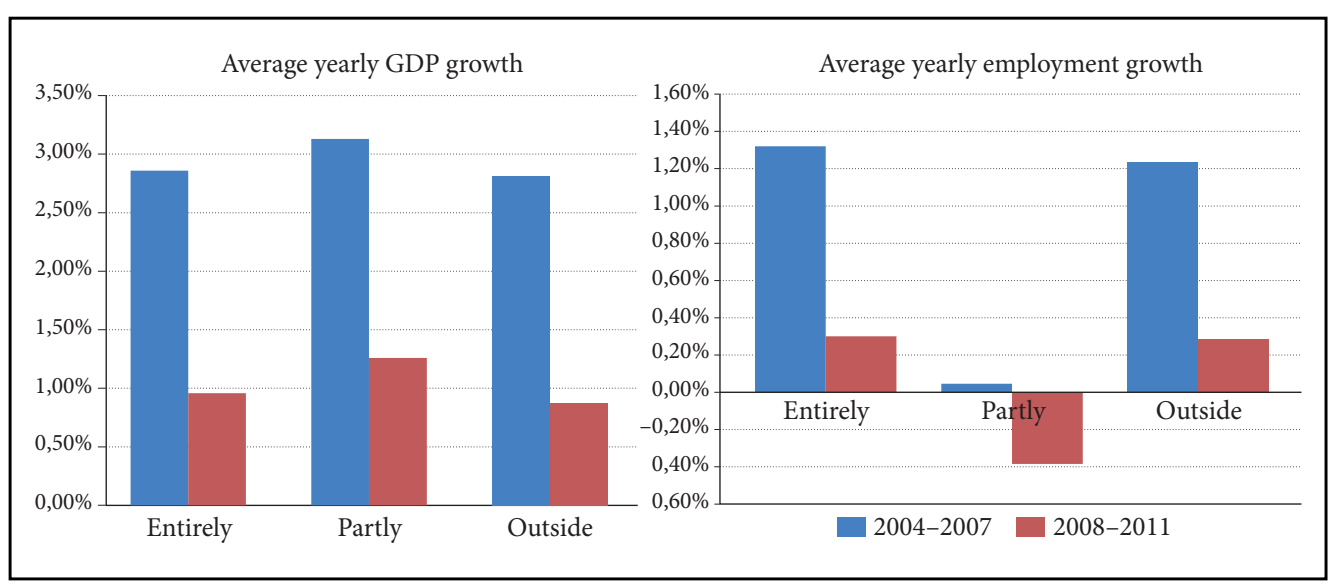

Figure 3: Average yearly GDP and employment growth in NUTS3 groups identified.

\section{Towards more resilient economies in the Alps: Conclusions}

Studying the effects of the economic crisis at the level of the entire Alpine Space Programme area indicates country-specific responses; namely, Italian and Slovenian regions perform worse than regions in other Alpine countries. This could be compared to the results of the Espon group (Economic Crisis: Resilience ... 2013), where major differences among countries are similarly noticeable. Consequently, regions cannot be understood as the only decisive factors in providing resilience because they strongly depend on the macroeconomic framework conditions of the entire country. Therefore the first step towards more resilient regions should be made at the national level, providing attractive socioeconomic conditions such as an innovation-friendly tax system, openness to foreign investment, a competitive business environment, a flexible employment system, and, above all, a trustworthy and stable political system that plays an important role in confidence building while interacting at the international level.

Sector-specific characteristics of the economic crisis can be overcome by a diversified mix of companies and sectors that can only be achieved in the long term. Residues of unprofitable economic activities remain for a long time and are often a burden to economic development. For example, unqualified workers, when unemployed, cannot meet the requirements for knowledge-intensive sectors, which are currently gaining in importance. In particular, human capital requires a longer period to adapt, and therefore educational policy should constantly strive to provide a highly skilled and flexible workforce that is able to change employment within the sector or even to pass on to another sector.

Special concern should be dedicated to the sector that represents the economic backbone of a region. Its resilience should be strengthened, but at the same time the crisis is an opportunity to improve and transform the regional economic structure. In this process, consensus among various regional actors is of vital importance, particularly when optimizing the use of regional resources.

The economic crisis in 2007 was an external factor more severely influencing regions that were strongly connected to the global market, be this through resource dependency or through their export activities. To increase their resilience, regions should increasingly mobilize their own resources, which is a challenging opportunity especially to the Alps because the Alps are perceived as one of the most resourceful regions in Europe.

Effects of the economic crisis quickly covered all of European territory, whereas recovery requires much more time (Economic Crisis: Resilience ... 2013). Differences in vulnerability and recovery between countries point to the role of a flexible economic system and the importance of a quick and coordinated response of all crucial actors - all levels of government (national, regional, and local), the public, and private sectors (Bagley 2012). A quick response and adaptability are crucial, particularly because changes are becoming one of the rare constants of the contemporary increasingly interconnected world. Successfully facing daily challenges might contribute to higher resilience in the long run. In this regard, actions must 
be taken as soon as the first signals of a change appear; no matter the size of a challenge, a prompt reaction could help in overcoming it more easily. To this end, constant monitoring of economic trends is mandatory.

According to the Organisation for Economic Co-operation and Development, a crisis is also the right time to introduce locally led strategic planning, to enhance administrative capacity and participation of regional stakeholders in decision-making process, and to introduce reforms, new standards, and higher accountability (Building ... 2013).

A proactive approach could considerably minimize the role of external economic factors; therefore cooperation of all crucial regional actors is desirable particularly concerning those measures aimed at safeguarding regional employment, which ultimately can contribute to increasing regional resilience. Not only can proactivity provide an adequate response to external challenges, it can also put regions in a position where they generate and lead a change.

As a European macro region, the Alps have a considerable advantage in terms of institutional and strategic settlement. On the one hand, the Alpine Convention, protocols, the permanent secretariat, and the contract parties (Alpine countries) build a solid institutional and legal framework for transnational dialogue on future sustainable development of the region. On the other hand, the Alpine Space Programme's transnational cooperation program provides funding for implementing projects, leading to a more attractive, accessible, competitive, and environmentally friendly macro-region. Because fostering regional resilience is one of the strategic goals, the next program period could considerably improve the economic performance of Alpine regions, and hopefully this will also raise the region's resilience.

\section{References}

Alpine Space Programme cooperation area, 2014. Internet: http://www.alpine-space.eu/about-the-programme/ asp-2007-2013/cooperation-area/ (12.8.2014).

Arestis, P., Sobreira, R., Oreiro, J. L. 2011: The financial crisis origins and implications. London.

Aubert, A., Jónás-Berki, M., Gergely, M. 2013: Tourism index as an indicator of the intensity of tourism. Acta geographica Slovenica 53-2. DOI: http://dx.doi.org/10.3986/AGS53205

Bagley, R. O. 2012: Building economic resilience in the $21^{\text {st }}$ century. Internet:

http://www.forbes.com/sites/rebeccabagley/2012/05/01/building-economic-resilience-in-the-21st-century/ (13.9.2014).

Bole, D. 2011: Changes in employee commuting: a comparative analysis of employee commuting to major Slovenian employment centers from 2000 to 2009. Acta geographica Slovenica 51-1. DOI: http://dx.doi.org/ 10.3986/AGS51104

Boschma, R., Frenken, K. 2011: The emerging empirics of evolutionary economic geography. Journal of economic geography 11-2. DOI: http://dx.doi.org/10.1093/jeg/lbq053

Briguglio, L., Cordina, G., Farrugia, N., Vella, S. 2008: Economic vulnerability and resilience. UNU-WIDER 55. Helsinki. Internet: http://www.wider.unu.edu/publications/working-papers/research-papers/ 2008/en_GB/rp2008-55/_files/79432653132595540/default/rp2008-55.pdf (27.6. 2012).

Bristow, G. 2014: Agency, choice and agenda: developing perspective on economic resilience. DLGS International conference on resilience in urban and regional development, Berlin, March 27-28 2014. Internet: http://www.dlgs-dresden.de/fileadmin/daten/Konferenz_2014/Presentations/Keynote_1_Bristow.pdf (21.8. 2014).

Building resilient regions: lessons for policy making in post-disaster regions, 2013. Organisation for economic co-operation and development. Internet: http://www.oecd.org/gov/regional-policy/resilient\% 20regions\%20flyer.pdf (14.9.2014).

Christopherson, S., Michie, J., Tyler, P. 2010: Regional resilience: theoretical and empirical perspectives. Cambridge journal of regions, economy and society 3-1. DOI: http://dx.doi.org/10.1093/cjres/rsq004

Economic crisis in Europe: causes, consequences and responses. European economy 7. Office for official publications of the European Communities. Luxemburg, 2009. Internet: http://dx.doi.org/10.2765/84540

Economic crisis: resilience of regions, 2013. Espon \& Cardiff university. Revisited interim report. Internet: http://www.espon.eu/export/sites/default/Documents/Projects/AppliedResearch/ECR2/ECR2_Revised_ Interim_Report.pdf (27.8.2013). 
Federal statistical office (FSO), 2014: gross domestic product (GDP) per region and canton, 2011. Internet: http://www.bfs.admin.ch/bfs/portal/en/index/themen/04/02/05/key/01.html (23. 7. 2014).

Figures for the future, 2012. 20 years of sustainable development in Europe? A guide for citizens. Internet: http://epp.eurostat.ec.europa.eu/cache/ITY_OFFPUB/KS-32-12-152/EN/KS-32-12-152-EN.PDF (14.7.2014).

Foster, K. A. 2010: Regional resilience: how do we know it when we see it? Buffalo. Conference on urban and regional policy and its effects. Washington D.C. Internet: http://www.regionalinstitute.buffalo.edu/Includes/ UserDownloads/Foster\%20DC\%20Presentation\%20v2\%20May\%202010.pdf (18. 12. 2013).

Gloersen, E., Bausch, T., Hurel, H., Pfefferkorn, W., del Fiore, F., Ratti, C., Zavodnik - Lamovšek, A. 2012: Strategy-development for the Alpine Space: key statements. Internet: http:/www.alpine-space.eu/fileadmin/ media/Downloads_in_about_the_programme/Key_statements.pdf (4.9.2014).

Graziano, P. 2013: Vulnerability and resilience of the economic, social and environmental dimensions of Italian provinces. Regional studies association European conference, 2013. Internet: http://www.regionalstudies.org/uploads/Graziano2013.pdf (14.2.2014).

Helleiner, E. 2011: Understanding the 2007-2008 global financial crisis: lessons for scholars of international political economy. Annual review of political science 14. DOI: http://dx.doi.org/10.1146/ annurev-polisci-050409-112539

Hill, E. W., Wial, H., Wolman, H. 2008: Exploring regional economic resilience. Berkeley institute of urban and regional development, University of California. Internet: http://escholarship.org/uc/item/7fq4n2cv\#page-1 (27.6.2012).

Kuhlicke, C., Steinführer, A., Begg, C., Bianchizza, C., Bründl, M., Buchecker, M., De Marchi, B., Di Masso Tarditti, M., Höppner, C., Komac, B., Lemkow, L., Luther, J., McCarthy, S., Pellizzoni, L., Renn, O., Scolobig, A., Supramaniam, M., Tapsell, S., Wachinger, G., Walker, G., Whittle, R., Zorn, M., Faulkner, H. 2011: Perspectives on social capacity building for natural hazards: outlining an emerging field of research and practice in Europe. Environmental science \& policy 14-7. DOI: http://dx.doi.org/10.1016/ j.envsci.2011.05.001

Lagravinese, R. 2014: Crisi economiche e resilienza regionale. EyesReg giornale di scienze regionali 4-2.

Martin, R. 2012: Regional economic resilience, hysteresis and recessionary shocks. Journal of economic geography 12-1. DOI: http://dx.doi.org/10.1093/jeg/lbr019

Matarrita-Cascante, D., Trejos, B. 2013: Community resilience in resource-dependent communities: a comparative case study. Environment and planning 45-6. DOI: http://dx.doi.org/10.1068/a45361

Mock, J., Easterbrook, P., Banks, A. 2013. Alpine shire council community resilience plan 2012-2015.

Internet: http://www.alpineshire.vic.gov.au/files/Being_prepard/2014COMMUNITY_RESILIENCE_PLAN_ 2012-2015.pdf (21.7.2014).

Resilience capacity index. 2013. Building resilient regions. Institute of governmental studies, the University of California Berkeley. Internet: http://brr.berkeley.edu/rci/ (28. 8. 2013).

Rizzi, P., Dallara, A. 2011: The local impact of the crisis in a sustainable perspective: the Italian case. Regional studies association annual international conference 2011, Piacenza. Internet: http://www.regionalstudies-assoc.ac.uk/events/2011/april-newcastle/papers/Rizzi.pdf (5.3.2012).

Ruffini, F. V., Streifeneder, T., Elselt, B. 2004. Anhang III: Definition des Perimeters der Alpenkonvention. Umweltbundesamtes. Berlin. Internet: http://www.alpconv.org/de/AlpineKnowledge/indicators/ Documents/annex3_de.pdf (2.7.2014).

Simmie, J., Martin, R. 2010: The economic resilience of regions: towards an evolutionary approach. Cambridge journal of regions, economy and society 3-1. DOI: http://dx.doi.org/10.1093/cjres/rsp029

Statistical office of the European Communities (EUROSTAT), 2014a. Regional statistics. Gross domestic product (GDP) at current market prices by NUTS 3 regions. Luxembourg. Internet: http://epp.eurostat.ec.europa.eu/ (23.7.2014).

Statistical office of the European Communities (EUROSTAT), 2014b. Regional Statistics. Employment (in 1000 persons) by NUTS 3 regions (NACE Rev. 2). Luxembourg. Internet: http://epp.eurostat.ec.europa.eu/ (23.7.2014).

Statistical Office of the European Communities (EUROSTAT), 2014c. Regional Statistics. Population on 1 January - Total. Luxembourg. Internet: http://epp.eurostat.ec.europa.eu/ (23.7.2014).

Statistical office of the European Communities (EUROSTAT), 2014d. Ratio of unemployed people in relation to overall work force regional statistics, table, Luxembourg. 
Šprah, L., Novak, T., Fridl, J. 2014. The wellbeing of Slovenia's population by region: comparison of indicators with an emphasis on health. Acta geographica Slovenica 54-1. DOI: http://dx.doi.org/10.3986/ AGS54104

The index of economic resilience 2011. Final report. Yorkshire, 2011. Internet: http://www.yorkshirecities.org.uk/ assets/files/Publications/Final\%20Report\%20final.pdf (27.6.2012).

Von Glasenapp, M., Thornton, T. F. 2011: Traditional ecological knowledge of Swiss Alpine farmers and their resilience to socioecological change. Human ecology 39-6. DOI: http://dx.doi.org/10.1007/ s10745-011-9427-6

Weichselgartner, J., Kelman, I. 2014: Geographies of resilience: challenges and opportunities of a descriptive concept. Progress in human geography. DOI: http://dx.doi.org/10.1177/0309132513518834

WIKIAlps. 2015. Internet: http://www.wikialps-project.eu (15.4.2015).

Wöhe, G., Döring U. 2010: Einführung in die Allgemeine Betriebswirtschaftslehre. 24. Auflage. München. 